Egypt. Acad. J. biolog. Sci., 2(2): 75 - 81 (2010)

Email: egyptianacademic@yahoo.com

Received: 5/11/2009
C. Physiology \& Molecular Biology

ISSN: 2090-0767

www.eajbs.eg.net

\title{
Biochemical effects of some agricultural waste extracts against Culex pipiens
} (Diptera: Culicidae)

\author{
Nadia Helmy ${ }^{1}$; Reda F. A. Bakr ${ }^{1}$; Galal A. Nawwar ${ }^{2}$; Somia El. Ibrahim ${ }^{2}$ and \\ Omnia M. Helmy ${ }^{2}$ \\ 1- Department of Entomology, Faculty of Science, Ain-Shams University \\ 2- Applied organic chemistry Department, National Research Centre, Cairo, Egypt
}

\begin{abstract}
Third larval instar of Culex pipiens were exposed to sub-lethal concentration $\mathrm{LC}_{25}$ of Black and White liquors (waste extract from rice straw) for 24 hours to study its effect on some enzymes activity along different developmental stages of mosquito.Acetylcholinesterase (AchE) enzyme showed high activity in all stages of mosquito treated in the larval stage with black and white liquors. Treatment with black and white liquors showed lower in enzyme activity of esterases ( $\alpha$-est, $\beta$-est) and Glutathione s-transferase (GST). While, mixed function oxidase (MFO) enzyme showed high activity in all developmental stages of $C$. pipiens larval treatment with black and white liquors in comparing with control except in pupal stage low activity and not affected, respectively.
\end{abstract}

Keywords: Enzymes activity, waste extracts, Culex pipiens

\section{INTRODUCTION}

The members of Culex pipiens complex are the most widely distributed species in the world Hoogstraal et al., (1977). In Egypt, the common house mosquito Culex pipiens has been recorded from all governorates without exception causing severe morbidity to man and animals. It is the main vector of Bancroftian filariasis (Sabry, 1991 and Harb, et al., 1993). It is also the vector of Rift Valley Fever in Egypt (Hoogstraal et al., 1979) and diseases caused by other viruses (Darwish and Hoogstraal, 1981). Recentlly, the plant extracts play an important role in an insect control, being considered to avoid the environmental pollution (Ansari et al., 2000; Gusmäo, et al., 2002; Bakr, et al. 2006 and Bakr, et.al 2008. Many natural plant compounds used in the control of insect pests are known to affect the enzymatic profiles (Nathan, et al., 2005). Glutathione-Stransferases (GSTs), esterases (ESTs) and cytochrome P450 monooxygenases (CYPs) are three major detoxifying enzymes in most organisms. At least one of them is involved in detoxification of insecticides in insects (Bull, 1981). P450 enzymes (mixed function oxidases - MFO -, cytochrome P450 monooxygenases), one of the most important enzyme system involved in insecticide detoxification or activation, are a complex family found in most organisms (Zhou and Huang, 2002). In insects, the diverse functions of P450 enzymes range from synthesis and degradation of ecdysteroids and juvenile hormones to the xenobiotics metabolism (Feyereisen, 2005). Insect GSTs have been implicated in resistance to insecticides, organophosphorous and pyrethroid, through direct insecticide metabolism (Wei, et al., 2001) or by protecting against secondry toxic effects, such as increases in lipid peroxidation, induced by insecticide exposure (Dou, et al., 
2009). A member of the esterase cluster probably plays a role in the detoxification of xenobiotic esters (Gacar and Tasksn, 2009). Also acetylcholinesterase (AChE), responsible for neurotransmitter degradation at the cholinergic nerve synapse, is the target of both organophosphate and carbamate insecticides. The use of bioinsecticides, the activity of $\mathrm{AChE}$ was decreased, due to the susceptibility of insects to these bioinsecticides (ElKady, et al., 2008) or increased, due to the new mode of action of newly derived avermectins (bioinsecticide) (Dahi, et al., 2009).

The aim of this study was to determine the effect of sub-lethal concentration of newly waste extracts from rice straw on the activity of some enzymes in different developmental stages (larvae, pupae, adult female and male) of Culex pipiens mosquito.

\section{MATERIALS AND METHODS Tested mosquitoes: Culex pipiens (Culicidae: Diptera)} Larvae of Culex pipiens provided from Medical Entomology Institute and transferred to the laboratory of Entomology Department - Faculty of Science - Ain Shams University where self-perpetuating colonies were established and maintained during the present study.

\section{Tested compounds}

Black liquor produced from the paper production industry but in new way patent No‘.(422 / 2008).

White liquor was effluent from bleaching paper that introduced in paper production industry (Sreekrishnan,2001) with modification, using sod. hyposulfite at $60^{\circ} \mathrm{C}$ with stirring for one day.

\section{Biochemical studies:}

Each of selected compounds was applied on larvae at concentration of LC25 level for $24 \mathrm{hrs}$. Then survived larvae post treatment were gently washed and transferred to labeled pans. Some of these survived larvae and other developmental stages emerged from treated larvae was collected and submitted to biochemical studies.

\section{Preparation of insects for analysis:}

Insects were homogenized for biochemical analysis in a chilled glass Teflon tissue homogenizer (ST-2 Mechanic-Preczyina, Poland). After homogenation, supernatants were kept in a deep freezer at $-20^{\circ} \mathrm{C}$ till use for biochemical assays. Double beam ultraviolet / visible spectrophotometer (spectronic 1201, Milton Roy Co., USA) was used to measure absorbance of colored substances or metabolic compounds.

\section{Estimation of acetylcholinesterase:}

AchE (acetylcholinesterase) activity was measured according to the method described by Simpson et.al., (1964) using acetylcholinebromide $(\mathrm{AchBr})$ as substrate. The reaction mixture contained $200 \mu \mathrm{l}$ enzyme solution, $0.5 \mathrm{ml} 0.067 \mathrm{M}$ phosphate buffer (pH7) and $0.5 \mathrm{ml} \mathrm{AchBr} \mathrm{(3}$ $\mathrm{mM})$. The test tubes were incubated at $37^{\circ} \mathrm{c}$ for exactly $30 \mathrm{~min} .1 \mathrm{ml}$ of alkaline hydroxylamine (equal volume of $2 \mathrm{M}$ hydroxylamine chloride and 3.5 $\mathrm{M} \mathrm{NaOH}$ ) was added to the test tubes. Then $0.5 \mathrm{ml}$ of $\mathrm{Hcl}$ (1 part of conc. $\mathrm{HCl}$ and 2 parts of $\Delta \mathrm{H}_{2} \mathrm{O}$ ) was added

The mixture shaken vigorously and allowed to stand for $2 \mathrm{~min} .0 .5 \mathrm{ml}$ of ferric chloride solution $(0.9 \mathrm{M} \mathrm{Fecl} 3$ in $0.1 \mathrm{M} \mathrm{HCl}$ ) was added and mixed well. The decrease in AchBr resulting from hydrolysis by AchE was read at $515 \mathrm{~nm}$.

Estimation of non-specific esterases:

Alpha esterases ( $\alpha$-esterases) and beta esterases ( $\beta$-esterases)were determined according to Van Asperen (I962) using $\alpha$-naphthyl acetate or $\beta$ naphthyl acetate as substrates, respectively. 
The reaction mixture consisted of $5 \mathrm{ml}$ substrate solution $(3 \times 10-4 \mathrm{M} \alpha$-or $\beta$ naphthylacetate, $1 \%$ acetone and $0.1 \mathrm{M}$ phosphate buffer, $\mathrm{pH} 7$ ) and $20 \mu 1$ of larval homogenate. The mixture was incubated for exactly $15 \mathrm{~min}$ at $27^{\circ} \mathrm{C}$, then $1 \mathrm{ml}$ of diazoblue color reagent (prepared by mixing 2 parts of $1 \%$ diazoblue $\mathrm{B}$ and 5 parts of $5 \%$ sodium lauryl sulphate) was added. The developed color was read at 600 or $555 \mathrm{~nm}$ for $\alpha$ - and $\beta$-naphthol produced from hydrolysis of the substrate, respectively. $\alpha$-and $\beta$-naphthol standard curves were prepared by dissolving $20 \mathrm{mg}$ $\alpha$ - or $\beta$-naphthol in $100 \mathrm{ml}$ phosphate buffer, $\mathrm{pH} 7$ (stock solution). Ten milliliters of stock solution were diluted up to $100 \mathrm{ml}$ by the buffer. Aliquots of 0.1 , $0.2,0.4,0.8$ and $1.6 \mathrm{ml}$ of diluted solution (equal to $2,4,8,16$ and $32 \mu \mathrm{g}$ naphthol) were pippeted into test tubes and completed to $5 \mathrm{ml}$ by phosphate buffer. One milliliter of diazoblue reagent was added and the developed color was measured as mentioned before.

\section{Estimation of oxidase activity:}

P-nitroanisole O-demthylation was assayed to determine the mixed function oxidase activity according to the method of Hansen and Hodgson (1971) with slight modification. The standard incubation mixture contained $1 \mathrm{ml}$ sodium phosphate buffer $(0.1 \mathrm{M}, \mathrm{pH} 7.6), 1.5 \mathrm{ml}$ enzyme solution, $0.2 \mathrm{ml} \mathrm{NADPH}$, (Final concentration $1 \mathrm{mM}), \quad 0.2 \mathrm{ml}$ glucose-6phosphate dehydro- genase (G-6PD). Reaction was initiated by the addition of p-nitroanisole in $10 \mu$ l of acetone to give a final concentration of $0.8 \mathrm{mM}$ and incubated for $30 \mathrm{~min}$ at $37^{\circ} \mathrm{C}$. Incubation period was terminated by addition of $1 \mathrm{ml}$ $\mathrm{HCl}(1 \mathrm{~N})$. P-nitrophenol was extracted with $\mathrm{CHCl} 3$ and $0.5 \mathrm{~N} \mathrm{NaOH}$ and absorbance of $\mathrm{NaOH}$ solution was measured at $405 \mathrm{~nm}$. An extinction coefficient of $14.28 \mathrm{mM}-1 \mathrm{~cm}-1$ was used to calculate 4-nitrophenol concentration.

\section{Estimation of Glutathione -S- transferase:}

Glutathione S-transferase(GST) catalyzes the conjugation of reduced glutathione (GSH) with 1-chloro 2,4dinitrobenzene (CDNB) via the $-\mathrm{SH}$ group of glutathione. The conjugate, $\mathrm{S}$ (2,4-dinitro-phenyl) - L - glutathione could be detected as described by the method of Habig et al.(I974). The reaction mixture consisted of $1 \mathrm{ml}$ of the potassium salt of phosphate buffer (pH6.5), $100 \mu \mathrm{l}$ of GSH and $200 \mu 1$ of larval homogenate. The reaction started by the addition of $25 \mu 1$ of the substrate CDNB solution. The concentration of both GSH and CDNB was adjusted to be $5 \mathrm{mM}$ and $1 \mathrm{mM}$, respectively

Enzyme and reagents were incubated at $30^{\circ} \mathrm{C}$ for $5 \mathrm{~min}$. The increment in absorbance at $340 \mathrm{~nm}$ was recorded against blank containing everything except the enzyme to determine the nanomole substrate conjugated $/ \mathrm{min} /$ larva using a molar extinction coefficient of $9.6 / \mathrm{mM} / \mathrm{cm}$.

\section{RESULTS}

Results represented in table (1) showed high AchE activity in all stages in black and white liquors larval treatment in comparing with control.

Table 1: Acetylcholinesterase activity in deferent developmental stages of Culex pipiens treated in larval stage with black and white liquors in comparison with non treated stages:

\begin{tabular}{|c|c|c|c|c|c|c|c|c|}
\hline \multirow{2}{*}{ Tested compounds } & \multicolumn{2}{|c|}{ Acetylcholinesterase $\mu \mathrm{g}$ AchBr released / min / g.b.wt } & \multicolumn{4}{|c|}{ Activity ratio* } \\
\cline { 2 - 9 } & Larvae & Pupae & Adult female & Adult male & Larvae & Pupae & Adult female & Adult male \\
\hline Black liquor & $24.17^{\mathrm{b}}$ & $34.43^{\mathrm{b}}$ & $180.67^{\mathrm{c}}$ & $88^{\mathrm{b}}$ & 1.10 & 1.55 & 1.19 & 1.44 \\
\hline White liquor & $23.50^{\mathrm{a}}$ & $37.27^{\mathrm{c}}$ & $160^{\mathrm{b}}$ & $80.67^{\mathrm{b}}$ & 1.06 & 1.68 & 1.06 & 1.32 \\
\hline Control & $21.97^{\mathrm{a}}$ & $22.17^{\mathrm{a}}$ & $150.67^{\mathrm{a}}$ & $61^{\mathrm{a}}$ & - & - & - & - \\
\hline
\end{tabular}

$*$ Activity ratio $=$

Enzyme activity in treated stages

Enzyme activity in control

Within a column, same latter mean no significant differences at 0.05 level of probability

Within a column, different letters mean significant differences at 0.05 level of probability 
The highest AchE activity showed in pupal stages which were 34.43 and 37.27 in black and white liquors treatment, respectively. As shown in table (1) pupal stage showed the highest enzymatic activity ratio in black and white liquors treatment, 1.55 and 1.68 , respectively as well as the larval stage showed the lowest enzymatic activity ratio in black and white liquors treatment, 1.10 and 1.06, respectively.

Different developmental stages C. pipiens larval treatment with black and white liquors showed lower in enzyme activity of $\alpha$-est than non treated stages as shown in table (2). The lowest enzyme activity showed in adult male which treated with white liquor.

Table 2: $\alpha$ Esterases activity in deferent developmental stages of Culex pipiens larval treatment with black and white liquors in comparison with non treated stages

\begin{tabular}{|c|c|c|c|c|c|c|c|c|}
\hline \multirow{2}{*}{ Tested compounds } & \multicolumn{2}{|c|}{$\alpha$ Esterases $\mu \mathrm{g} \alpha$-naphthol released / min / g.b.wt } & \multicolumn{5}{|c|}{ Activity ratio* } \\
\cline { 2 - 9 } & Larvae & Pupae & Adult female & Adult male & Larvae & Pupae & Adult female & Adult male \\
\hline Black liquor & $1713.7^{\mathrm{b}}$ & $697^{\mathrm{b}}$ & $4005.67^{\mathrm{a}}$ & $2540^{\mathrm{a}}$ & 0.90 & 0.73 & 0.92 & 0.94 \\
\hline White liquor & $1825.7^{\mathrm{a}}$ & $838^{\mathrm{a}}$ & $3402^{\mathrm{b}}$ & $1584.33^{\mathrm{b}}$ & 0.97 & 0.87 & 0.78 & 0.58 \\
\hline Control & $1876^{\mathrm{a}}$ & $958^{\mathrm{a}}$ & $4340^{\mathrm{a}}$ & $2711.33^{\mathrm{a}}$ & - & - & - & - \\
\hline
\end{tabular}

* Activity ratio $=$

Enzyme activity in treated stages

\section{Enzyme activity in control}

Within a column, same latter mean no significant differences at 0.05 level of probability

Within a column, different letters mean significant differences at 0.05 level of probability

The enzymatic activity ratio ranged from 0.58 to 0.97 in white liquor treatment, while ranged between 0.73 and 0.94 in black liquor treatment. Also, results represented in table (3) showed lower activity of $\beta$-est enzyme in all developmental stages of larval treatment with black and white liquors.
The lowest enzyme activity showed in adult male which treated with white liquor. The values of enzymatic activity ratio ranged from 0.50 to 0.98 in white liquor treatment while, ranged from 0.56 to 0.90 in black liquor treatment.

Table 3: $\beta$ Esterases activity in deferent developmental stages of Culex pipiens larval treatment with black and white liquors in comparison with non treated stages.

\begin{tabular}{|c|c|c|c|c|c|c|c|c|}
\hline \multirow{2}{*}{$\begin{array}{l}\text { Tested } \\
\text { compounds }\end{array}$} & \multicolumn{4}{|c|}{$\begin{array}{c}\beta \text { Esterases } \mu \mathrm{g} \alpha \text {-naphthol released / min / } \\
\text { g.b.wt }\end{array}$} & \multicolumn{4}{|c|}{ Activity ratio* } \\
\hline & Larvae & Pupae & $\begin{array}{l}\text { Adult } \\
\text { female }\end{array}$ & $\begin{array}{l}\text { Adult } \\
\text { male }\end{array}$ & Larvae & Pupae & Adult female & $\begin{array}{l}\text { Adult } \\
\text { male }\end{array}$ \\
\hline Black liquor & $664.33^{b}$ & $269.7^{b}$ & $1314.33^{b}$ & $813.67^{b}$ & 0.90 & 0.56 & 0.59 & 0.73 \\
\hline White liquor & $721.67^{\mathrm{a}}$ & $451.33^{\mathrm{a}}$ & $1195.67^{\mathrm{c}}$ & $562.67^{\mathrm{c}}$ & 0.98 & 0.93 & 0.53 & 0.50 \\
\hline Control & $739^{\mathrm{a}}$ & $485.33^{\mathrm{a}}$ & $2249.67^{\mathrm{a}}$ & $1119.67^{\mathrm{a}}$ & - & - & - & - \\
\hline
\end{tabular}

Within a column, same latter mean no significant differences at 0.05 level of probability Within a column, different letters mean significant differences at 0.05 level of probability

\section{Results in table (4) indicated} that, the MFO enzyme showed high activity in all developmental stages of C. pipiens larval treatment with black and white liquors in comparing with control except in pupal stage low activity and not affected in black and white liquors treatment, respectively. The values of enzymatic activity ratio were ranged between 1.00 and 1.58 in white liquor treatment and from 0.82 to 1.68 in black liquor treatment. 
Table 4: Mixed function oxidase activity in deferent developmental stages of Culex pipiens larval treatment with black and white liquors in comparison with non treated stages.

\begin{tabular}{|c|c|c|c|c|c|c|c|c|}
\hline \multirow{2}{*}{$\begin{array}{l}\text { Tested } \\
\text { compounds }\end{array}$} & \multicolumn{4}{|c|}{$\begin{array}{l}\text { Mixed function oxidase } \mu \mathrm{g} \text { nitrophenol released / } \\
\min / \text { g.b.wt }\end{array}$} & \multicolumn{4}{|c|}{ Activity ratio* } \\
\hline & Larvae & Pupae & Adult female & Adult male & Larvae & Pupae & $\begin{array}{l}\text { Adult } \\
\text { female }\end{array}$ & $\begin{array}{l}\text { Adult } \\
\text { male }\end{array}$ \\
\hline Black liquor & $55.91^{\mathrm{c}}$ & $50.40^{\mathrm{b}}$ & $70.73^{b}$ & $77.33^{b}$ & 1.68 & 0.82 & 1.22 & 1.32 \\
\hline White liquor & $52.60^{\mathrm{b}}$ & $61.50^{\mathrm{a}}$ & $66.67^{b}$ & $70.77^{b}$ & 1.58 & 1.00 & 1.15 & 1.21 \\
\hline Control & $33.23^{\mathrm{a}}$ & $61.31^{\mathrm{a}}$ & $57.80^{\mathrm{a}}$ & $58.37^{\mathrm{a}}$ & - & - & - & - \\
\hline \multicolumn{9}{|c|}{ Enzyme activity in treated stages } \\
\hline
\end{tabular}

Within a column, same latter mean no significant differences at 0.05 level of probability

Within a column, different letters mean significant differences at 0.05 level of probability

Pupal stage of C. pipiens showed lower enzyme activity of (GST) in both treatments than control but larval stage showed low enzymatic activity in black liquor only. As well as, larval stage which treated with white liquor and adult female and male treated with both black and white liquors showed slightly high and no effect in the enzyme activity as shown in table (5).

Table 5: Glutathion-s-transferase activity in deferent developmental stages of Culex pipiens larval treatment with black and white liquors in comparison with non treated stages.

\begin{tabular}{|c|c|c|c|c|c|c|c|c|}
\hline \multirow{2}{*}{$\begin{array}{l}\text { Tested } \\
\text { compounds }\end{array}$} & \multicolumn{4}{|c|}{$\begin{array}{l}\text { Glutathione-s-transferase } \mathrm{n} \text { mole substrate } \\
\text { conjugated /min / g.b.wt }\end{array}$} & \multicolumn{4}{|c|}{ Activity ratio* } \\
\hline & Larvae & Pupae & Adult female & Adult male & Larvae & Pupae & $\begin{array}{l}\text { Adult } \\
\text { female }\end{array}$ & $\begin{array}{l}\text { Adult } \\
\text { male }\end{array}$ \\
\hline Black liquor & $37.28^{b}$ & $44.63^{b}$ & $116.33^{\mathrm{a}}$ & $176^{\mathrm{a}}$ & 0.81 & 0.56 & 1.02 & 1.00 \\
\hline White liquor & $48.97^{\mathrm{a}}$ & $43.43^{b}$ & $121.33^{\mathrm{a}}$ & $173^{\mathrm{a}}$ & 1.07 & 0.54 & 1.07 & 0.99 \\
\hline Control & $45.90^{\mathrm{a}}$ & $80.17^{\mathrm{a}}$ & $113.67^{\mathrm{a}}$ & $175^{\mathrm{a}}$ & - & - & - & - \\
\hline
\end{tabular}

* Activity ratio $=$

Enzyme activity in treated stages

Enzyme activity in control

Within a column, same latter mean no significant differences at 0.05 level of probability

Within a column, different letters mean significant differences at 0.05 level of probability

These results appear clearly in values of enzymatic activity ratio. In pupal stage the enzymatic activity ratio were 0.56 and 0.54 in black and white liquors treatment. Larval stage which treated with black liquor its enzymatic activity ratio was 0.81 while all remaindering stages showed enzymatic activity ratio ranged between 0.99 and 1.07 .

\section{DISCUSSION}

The obtained results of AchE activity during different developmental stages showed significantly high difference in all stages emerged from larval treatment with black liquor more than white liquor except pupal stage only showed significantly high difference in white liquor treatment more than black liquor. Dahi et al., (2009) stated that producing an extra release of AchE which may prevents principally any message to be sent to the receptor and thus the insect become without neural orientation.

The results of larval treatment with both black and white liquors showed reduction in $\alpha$-Est activity during all developmental stages. These results indicated that the tested compounds cannot detoxify by this enzyme. Similar conclusion achieved by Mona Abd El-aziz and El-Sayed, (2009). Susciptibility of $C$. pipiens to black liquor was more than white liquor according to their values of enzymatic activity ratio. The obtained results of $\beta$ - Est activity showed reduction in both black and white liquors treatment during all developmental stages. These results explained that this enzyme play no role in the detoxification of tested compounds as stated before by Mona Abd El-aziz and El-Sayed, (2009). 
The larval treatment with both black and white liquors showed significantly high difference in all developmental stages of $C x$. pipiens for MFO enzyme activity except pupal stage showed low and no change activities in black and white liquor respectively. These results indicated that this enzyme may play role in detoxifying tested compounds as a self defense to protect themselves as stated by Terriere (1984). On the other hand, increasing in MFO enzyme activity may be due to these tested compounds act as juvenile hormone analogues, which were cytochrome P450 inducers in insect (Wilkinson, 1976).

The obtained results showed reduction in enzyme activity of GST during larval stage as a result of black liquor treatment. As well as, during pupal stage the enzyme showed reduction in its activity by both treatments. The suppression of detoxification enzyme indicated that this enzyme play no role in detoxification of black and white liquors and may be increase the susceptibility of $C x$. pipiens to the tested compounds as stated by Mona Abd El-aziz and El-Sayed, (2009).

In conclusion the increase in MFO and $\mathrm{AChE}$ in different developmental stages of mosquito emerged from larvae treated by both Black and White liquors suggest that these enzymes may be play role in detoxification of tested compounds or these compounds acts as juvenile hormone analogues and extra release of AchE may prevents principally any message to be sent to the receptor and thus the insect become without neural orientation. The suppression of other enzymes indicated that these enzymes play no role in the detoxification of tested compounds and may be increase the susceptibility of the $C x$. Pipiens mosquito to the tested compounds.

\section{REFERENCE}

Hoogstraal, H.; Mefgan, J.M.; Khalil, G.M. and Adhamf, F.K. (1977): The Rift valley fever epizootic in Egypt 1977 - 1978. 2. Ecological and Entomological studies. Trans.
Roy. Soc. Trop. Med. Hyg., 73: 624-729.

Sabry, M. (1991): A new realistic index of experimental transmission efficiency for Bancroftian filariasis. J. Trop. Med. Hyg., 94 (4): 283-290.

Harb, M.; Faris, R.; Hafez, O.N.; Ramzy, R. and Buck, A.A. (1993): The resurgence of lymphatic filariasis in the Nile Delta. Bull. WHO, 71 (1): 49-54.

Dawish, M. and Hoogstraal, (1981): Arboviruses infecting humans and lower animals in Egypt: A review of thirty years of research. J. Egypt Public Health Assoc., 56: 112.

Bull,D.L. (1981): Factors that influence tobacco budworm, Heliothis virescens, resistance to organophosphorous insecticides. Bull. Entomol. Soc. Amer., 27: 193-197.

Dou, W.; Shuang, Wu.; Hassan, M.W. and Jin-Jun, W. (2009): Purification and biochemical characterization of glutathione S-transferases from three strains of Liposcelis bostrychophila Badonnel (Psocoptera: Liposcelididae): Implication of insecticide resistance. Pestic. Biochem. Physiol., 94: 10-14.

Feyereisen, R. (2005): Insect cytochrome P450. In Gilbert, L.I.; Iatrou, K. and Gill, S. (Eds.), Comperhensive Insect Physiology, Biochemistry, Pharm. Mol. Biol. Elsevier, Amsterdam, 1-77.

Gacar, F. and Tasksn, V. (2009): Partial base sequence analysis of MdaE7 gene and ali-esterase enzyme activities in the field collected populations of housefly (Musca domestica L.) from Mediterranean and Aegean Regions of Turkey. Pestic. Biochem. Physiol., 94: 86-92.

Zhou, G.L. and Huang, J.L. (2002): Diversity and evolution of CYP6 family in insects. Entomol. Knowl., 39: 4246-4251.

Ansari, M. A.; Razdan, R. K.; Mamta, T.; Padma, V.; Tandon, M.; and Vasudevan, P. (2000):Larvicidal 
and repellent actions of Dalbergia sissoo Roxb. (F: Leguminosae) oil against mosquitoes. Bioresource Tech., 73 (3): 207-211.

Bakr, R.F.A.; ElBermawy, S.M.; Geneidy, N.A.M.; Emara, S. A. and Hassan, H.W. (2006): Occurrence of the biological effects of some plant extracts on the cotton leaf worm Spodoptera littoralis (Biosd) and their physiological. Egypt. Acad. Soc. Environ. Develop., 7 (1): 109-147.

Bakr, R.F.A.; Hussein, M.A.; Hamouda, L.S.; Hassan, H.A. and Elsokary, Z.F. (2008): Effect of some insecticidal agents on some biological aspects and protein patterns of desert locust Schistocerca gregaria (Forskal). Egypt. Acad. Soc. Environ. Develop., 9 (2): 29-42.

Gusmäo, D. S.; Páscoa, V.; Mathias, L.; Vieira, I. J. C.; Braz-Filho, R.; and Lemos, F. J. A. (2002):Derris (Lonchocarpus) urucu (Leguminosae) Extract Modifies the Peritrophic Matrix Structure of Aedes aegypti (Diptera:Culicidae). Mem Inst Oswaldo Cruz, Rio de Janeiro, 97(3): 371-375.
ElKady, G.A.; Kamel, N.H.; Mosleh, Y.Y. and Bahght, I.M. (2008): Comparative toxicity of two bioinsecticides (Spinotoram and Vertemic) campared with Methomyl against Culex pipiens and Anopheles multicolor. World J. Agric. Sci., 4 (2): 198-205.

Dahi, H.F.; El-Sayed, Y.A.; El-Barkey, N.M. and Abd-ElAziz, M.F. (2009): Toxicological and biochemical studies of methylamine avermactin, a new type of bioinsecticide against the cotton leaf worm, Spodoptera littoralis (Biosd). Egypt. Acad. J. Biol. Sci., 2 (1): 103-116.

Nathan, S.S.; Kalaivan, K. and Chung, P.G. (2005): The effect of azadirachtin and nucleopolyhedrovirus on midgut enzymatic profile of Spodoptera litura Fab. (Lepidoptera: Noctuidae) Pestic. Biochem. Phys., 83 (1): 46-57.

Sreekrishnan, M.A.T.R. (2001): Aquatic toxicity from pulp and paper mill effluents: a review. Adv. Environ. Res., 5: 175-196.

\section{ARABIC SUMMARY}

$$
\begin{aligned}
& \text { تأثيرات كيمو حيوية لبعض مستخلصات المخلفات الزراعيةعلى بعوضة، كيوليكس بيينز (ديبترا:كيوليسيدي) }
\end{aligned}
$$

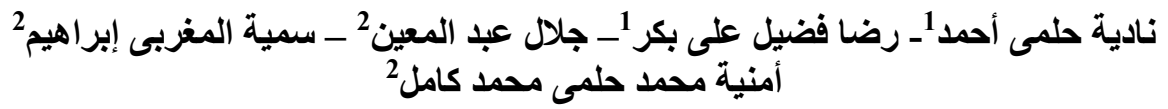

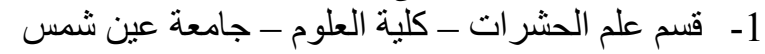

$$
\begin{aligned}
& \text { 2- ق قسم الكيمياء العضوية التطبيقية ـ- المركز القومى للبحوث }
\end{aligned}
$$

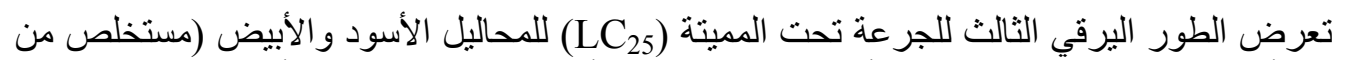

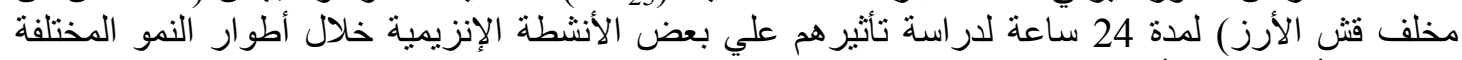

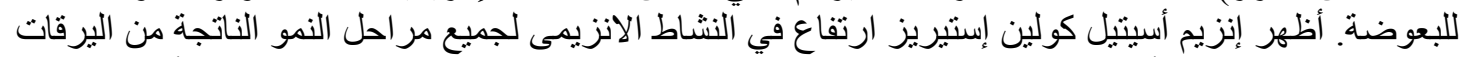

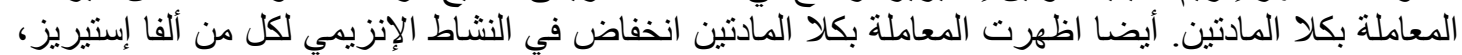

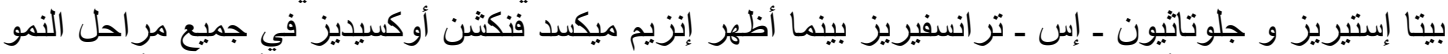
ماعدا طور العذراء أظهر انخفاض و عدم تاثير لنتشاط الإنزيم نتيجة للمعاملة بالمحاليل الأسود و الأبيض علي الئي 